\title{
Research on the logistics management in the enterprise supply chain system
}

\author{
Liyan Zuo ${ }^{1, a}$, Yong Wang ${ }^{2, b}$ \\ ${ }^{1}$ Department of industry and business administration, Daqing Vocational College, Daqing 163000 \\ China; \\ ${ }^{2}$ Oilfield Special Products Manufacturing Branch, Daqing Petroleum Equipment Group, Daqing \\ 163000 China \\ azuoliyan82@126.com; 'bangyong1042@163.com
}

Keywords: Enterprise; Logistics management; Supply chain

\begin{abstract}
Recently, the competition of the modern enterprises is focus on the competition of the supply chain management and logistics management. Therefore, the supply chain management is becoming more and more important in the world economy, and it has changed the ways of the logistics management. In this paper, the logistics management in the enterprise supply chain system was researched, and the theory of supply chain system was also discussed, Finally, some proposes and methods for improving the level of supply chain logistics management were elaborated.
\end{abstract}

\section{Introduction}

In the supply chain system, logistics management has all along played a pivotal role. In the supply chain, logistics management is an important sign differ from traditional logistics management. Supply chain and logistics management has seemed more and more important in business management, people pay attention to Lenovo, Nokia, Toyota, etc. because these enterprises have advanced supply chain logistics management capabilities, advanced logistics technology and outstanding logistics management personnel, these enterprises are advocate and facilitator under supply chain logistics management, through the supply chain logistics management can directly enhance the competitiveness of enterprises [1, 2].

Supply chain concept: Development of the supply chain concept has undergone a long process, the Supply Chain Association said: Supply chain, including the entire process of the production and delivery of final goods and services, from the supplier's supplier to the customer's customer. In general, the so-called supply chain is the product in the production and distribution process involved producers, wholesalers, retailers and consumers formed a network of supply and demand. Supply chain itself is not just a material chain, information chain, the capital chain, is a value-added chain connecting supplier to users [3]. Supply chain is a huge logistics system, it is network-like structure. In the supply chain, an enterprise is a node, there is a demand and supply relationship between each node, the supply chain has some distinctive features:

(1) Complexity. Enterprises on the supply chain nodes often consist of many types of enterprise structure, so the supply chain structure model is more complex than a single enterprise model, and it is more uncertain.

(2) Supply chain is a whole. It is the overall objective of the center, it is a strong cooperative and competitive modes, not only by the procurement, manufacturing, sales and other activities to build the separation mode. Each node in enterprise supply chain are inseparable, it is closely linked organic whole.

(3) With dynamic and cross-cutting nature. In order to adapt to the market and changes in corporate strategy better, node enterprises on supply chain need to constantly seek change. Node Enterprises as the main member of the supply chain, which itself is another member of the supply chain, and so forth continues, it will form a cross complex structure, the difficulty of management will also increase.

\footnotetext{
${ }^{1}$ Corresponding author: Liyan Zuo (1973-), female, Acheng County, Heilongjiang Province, E-mail: zuoliyan82@126.com
} 
(4) It is a logistics chain, information chain, the capital chain and value-added chain. The entire process of products from manufacturing enterprises to the end user can be reflected in the supply chain. While it enables the common benefit of all participants, logistics and after a series of processes in the supply chain adds value to the product, it can bring value-added benefits to the relevant enterprises [4].

\section{Problems in supply chain logistics management}

\section{Traditional management ideas and methods ingrained affect efficiency of enterprise logistics.}

At present, many enterprises still maintain the integration operation of production, supply and warehousing, transport through-train, logistics activities mainly rely on internal to complete, procurement, warehousing and distribution functions were not fully integrated, it is not conducive to social professional division of labor, and difficult to emerge supply chain logistics management benefit. With the deepening of economic globalization, customers require the logistics showing a personalized, diversified trend. When many enterprises in China formulating logistics service standards, they tend to average allocate the limited resources, and this affected the logistics service performance and customers satisfaction. Enterprise logistics service management is carried out by the logistics sector alone, enterprises management department can not keep abreast of the logistics services implementation, it affects the effectiveness of logistics services.

\section{Supply chain enterprises logistics infrastructures are obsolete, the degree of information technology is low.}

Our enterprise logistics obsolete equipment, low degree of information technology, single function, the efficiency is relatively low, it is difficult to meet the needs of modern logistics development. Since the infrastructure is relatively backward, lack of standards, such items in the transport, storage and other aspects are difficult to achieve overall, the whole process flow. At present, the development of information technology in the field of logistics is uneven, it is difficult for enterprises to achieve docking with the network and supply chain management. E-commerce technology in the supply chain logistics management did not get very good use, the level of automation of logistics operations is lower. In the supply chain logistics management, a lack of the help of modern information technology, a large number of logistics information flow is blocked in different departments, which not only affects the logistics operation efficiency of each node enterprise, resulting in a large number of resource consumption can not be fully utilized, increased logistics costs, but also directly affect the overall competitiveness of the supply chain.

\section{Many uncertainties in enterprises supply chain logistics management.}

In traditional logistics management on the existence of great uncertainty, which causes the logistics and information flow fails, makes the risk of Enterprises logistics management. In the supply chain systems, each node enterprises are interrelated, a lot of uncertainty and risk are likely to be amplified. Suppliers, producers and customers on the supply chain node, both node enterprises and upstream and downstream enterprises exist uncertainty. Enterprise supply chain logistics management is to ensure the effective flow of logistics and information flow in supply chain, and the uncertainties in the supply chain will bring great trouble to logistics management. Uncertainties lead to supply chain logistics exist on each node, so that each part of the entire supply chain will be at risk. .

\section{Lack of good logistics personnel.}

Since the process of globalization continues to accelerate, in this backdrop, enterprises need the complex logistics personnel who are proficient in foreign languages, import and export trade, e-commerce and procurement systems. However, the culture of China logistics education and logistics personnel are still lag behind, college logistics courses are without system, logistics personnel single skill, which can not meet the needs of the present stage of logistics management in our country. This situation greatly limits the development of China's logistics industry, enterprise logistics management level is also difficult to improve. Many enterprises ignore training logistics management personnel, does not provide continuing education opportunities for existing logistics 
personnel, resulting in many logistics personnel can not meet the enterprise needs of modern logistics management, thereby restricting the healthy development of logistics enterprises.

\section{The measures for improving supply chain enterprise logistics management level}

\section{Attention to logistics management from a strategic height.}

Enterprises should rise the supply chain logistics management to the height of corporate strategy, supply chain logistics management is not just the immediate development of enterprise management, but a long-term development plan, the enterprise competition in the future is the competition between the supply chain,enterprises should attach great importance to supply chain logistics management, take active part in forming the strategic alliances with other enterprises. Enterprises in logistics strategic alliance could efficiently utilize the dual advantage of organizations and markets, through a long-term and stable strategic partnership of cooperation, give full play to the advantages of the whole supply chain to compete, improve product competitiveness and market share, while achieving mutual benefit.

\section{Innovative logistics concepts.}

Modern enterprise logistics service concept is to customer demand for the center. This requires enterprises to change the past business philosophy, established to meet the needs of the diverse requirements of customers logistics services. It can be achieved through innovative logistics services and logistics service. In order to better reach customer expectations, logistics management must be based on customer demand, on various aspects of logistics management and constant innovation services, to provide customers with differentiated logistics services to better access to customer satisfaction. Enterprises have been actively involved in logistics management and operation for customers, and establish effective communication channels with them, build a good communication platform, make efforts to change the traditional way of doing business, form a mutual communication interaction trading situation with customers, which can make the synergistic effect between enterprises and customers.

\section{Adopt advanced logistics technology, to play the role of modern information technology.}

Impact of electronic commerce on supply chain management gradually, and with the continuous development of information technology, modern e-commerce is also growing. Supply chain management of modern e-commerce platform is the combination of e-commerce and supply chain management, customer-centric, make integration of the various parts of the supply chain closely integrated, it is conducive to implementation of supply chain management based e-commerce platform by enterprises and customers, which can not only enhance the efficiency of the entire supply chain, retain existing customers, but also attract new customers to join the supply chain, increase new business. The enterprises should seize the opportunity, while the positive development of the logistics industry, and more channels to introduce foreign advanced technology in logistics management to transform our logistics infrastructure, and enhance their competitiveness, thus narrowing the gap between China's logistics industry with the world advanced level .

\section{Increase training efforts of logistics personnel.}

Logistics personnel training is the key to the supply chain enterprise logistics management development. Enterprises must vigorously develop modern logistics management personnel, strengthen exchanges and cooperation between the management consulting firm, make consulting firm to provide practical guidance for the training of logistics personnel; enterprises should provide more opportunities for the logistics personnel, establish survival of the fittest competition mechanism for logistics personnel, make more prominent logistics personnel involved in logistics management; trying to learn foreign advanced logistics management experience, combined with the practice of logistics management, form a number of innovative ability of logistics management personnel. At the same time, the government should support training logistics personnel, encourage social service agencies to help enterprise training supply chain logistics management personnel. Universities should combine the theory and practice of logistics management, schools can establish a good working relationship with a number of enterprises, so that students have more opportunities to reach the logistics supply chain management practices of enterprises, enhance logistics 
management in practice knowledge and understanding.

\section{Conclusion}

In the supply chain system, logistics management has all along played a pivotal role. In the supply chain, logistics management is an important sign differ from traditional logistics management. Modern enterprise logistics service concept is to customer demand for the center. This requires enterprises to change the past business philosophy, established to meet the needs of the diverse requirements of customers logistics services. At the same time, the government should support training logistics personnel, encourage social service agencies to help enterprise training supply chain logistics management personnel.

\section{References}

[1] X.L. Wang, H.J. Li. Research on the logistics cost and control [J]. Logistics Technology, 2006, vol. 3, pp. 21-25.

[2] Y. Tao. Current situation and thinking of SMEs in logistics management [J]. Enterprise economy, 2011, vol. 1, pp. 58-60.

[3] Q. Zheng. Logistics management and the method of realizing modernization [J]. China Cement, 2002, vol.7, pp. 45-49.

[4] H.T. Li. Longitudinal control of the logistics cost [J]. Business Management, 2015, vol. 5, pp.13-17. 